\title{
High-Resolution Monsoon Records Since Last Glacial Maximum: A Comparison of Marine and Terrestrial Paleoarchives from South Asia
}

\author{
Manish Tiwari, ${ }^{1}$ Ashutosh K. Singh, ${ }^{2,3}$ and Rengaswamy Ramesh ${ }^{2}$ \\ ${ }^{1}$ National Centre for Antarctic \& Ocean Research, Headland Sada, Vasco, Goa 403804, India \\ ${ }^{2}$ Geosciences Division, Physical Research Laboratory, Navrangpura, Ahmedabad 380009, India \\ ${ }^{3}$ Department of Geology, University of Delhi, New Delhi 110007, India
}

Correspondence should be addressed to Rengaswamy Ramesh, rramesh@prl.res.in

Received 28 December 2010; Accepted 11 April 2011

Academic Editor: Atle Nesje

Copyright (C) 2011 Manish Tiwari et al. This is an open access article distributed under the Creative Commons Attribution License, which permits unrestricted use, distribution, and reproduction in any medium, provided the original work is properly cited.

\begin{abstract}
Agricultural production and the availability of fresh water in Indian subcontinent critically depend on the monsoon rains. Therefore it is vital to understand the causal mechanisms underlying the observed changes in the Indian monsoon in the past. Paleomonsoon reconstructions show that the water discharge from the Ganges-Brahmaputra River system to the Bay of Bengal was maximum in the early to mid-Holocene; data from the Western Arabian Sea and Omanian speleothems indicate declining monsoon winds during the Holocene, whereas records from the South West Monsoon (SWM) precipitation dominated eastern Arabian Sea show higher runoff from the Western Ghats indicating gradually increasing monsoon precipitation during the Holocene. Thus there exists considerable spatial variability in the monsoon in addition to the temporal variability that needs to be assessed systematically. Here we discuss the available high resolution marine and terrestrial paleomonsoon records such as speleothems and pollen records of the SWM from important climatic regimes such as Western Arabian Sea, Eastern Arabian Sea, Bay of Bengal to assess what we have learnt from the past and what can be said about the future of water resources of the subcontinent in the context of the observed changes.
\end{abstract}

\section{Introduction}

The Indian economy is based on agriculture, which mostly depends on the monsoon rain and to some extent on river flow and ground water resources. In the absence of monsoon that brings adequate rain, crop yield is reduced and due to recurrent droughts there may even be severe shortage of drinking water. The water resources of India comprise rivers, lakes, and ground water aquifers and the amount of water they hold is linked to the rainfall on the one hand and human exploitation on the other. Thus it is important to have a correct long-term forecast of the monsoon that can help in the proper management of our water resources [1]. Monsoon prediction is seriously hampered by the nonavailability of past data, which is limited to about hundred years [2]. It is very difficult to predict the monsoon without understanding its full variability. Generating quantitative paleomonsoon data using available, dateable, natural archives, such as deep sea and lake sediments, varved sediments, and speleothems is a starting point towards this end [3-6].

Monsoon is a term derived from an Arabic word "Mausim" meaning weather. It is technically applied to the seasonal reversal of winds in the Indian subcontinent and Africa, especially in the Arabian Sea, due to land-sea thermal and pressure contrast. It is mainly due to coupled heating and cooling of Himalaya (Tibetan plateau) and the southern Indian Ocean and the consequent movement of the ITCZ [7]. The Asian monsoon system is a dynamic component of the modern climate system and changes in this convectively active region can result in severe droughts or floods over large, densely populated regions [8]. The inherent seasonality of monsoon circulation leads to cool, dry winters and warm, wet summers over the Asian landmass. These seasonal changes in atmospheric circulation and precipitation also affect the ocean, leading to a strong seasonality in the strength and direction of ocean currents, sea-surface 
temperature (SST), and salinity patterns, as is observed in the Indian Ocean and the South China Sea (SCS). In specific regions, such as the Northwestern Arabian Sea, these dynamics lead to well-defined seasonal upwelling regimes in the open-ocean and near-shore environments [9]. The south Asian monsoon has been known to be stronger during warm climate (interglacial/interstadial) and weaker during cooler periods (glacial/stadial) ([10] and references therein), while the winter monsoon behaves the other way [11-13]. Thus monsoons are components of the global climate that play an important role in water resources of the Indian subcontinent.

The Southwest monsoon (SWM) occurs during June to September and the Northeast Monsoon (NEM) affects the southern parts of the Indian subcontinent during October to December [14]. AISRTS (All India Summer Monsoon Rainfall Time Series) is available from 1871 onwards [15], which has documented the last $\sim 140$ years of rainfall. If rainfall exceeds by more than $10 \%$ from the long-term average, it is called as excess rainfall year, while when it is lower by $10 \%$ or more, it is a deficient rainfall year. But to understand full variability of monsoon, which assumes added importance in view of the presently experienced global warming, we require records of monsoon during differing climatic conditions extending back to thousands of years.

\section{Multiproxy Comparison of Studies from Different Regions}

Evolution and variability of the Asian monsoon system are believed to respond to at least five types of large-scale climate forcing or changes in boundary conditions [49], including (i) the tectonic development of the HimalayanTibetan orography, in million-year time scales, (ii) changes in the atmospheric $\mathrm{CO}_{2}$ concentration, in time scales of tens of thousand of years, (iii) changes in the Earth's orbit that result in periodic variations of seasonal solar radiation, in time scales of tens of thousands of years, (iv) changes in the extent of ice sheets (thousand years time scales), and (v) internal feedbacks within the climate system (multiple-time scales). These factors act simultaneously and over different time scales to amplify or lessen the seasonal development of continental heating/cooling, land-sea pressure gradients, latent heat transport, and moisture convergence, all of which control the strength of the monsoon circulation. We present below a comparative analysis of multiproxy studies from diverse terrestrial (speleothems-stalactites and stalagmites from Indian and Oman caves) and marine (western, northern and eastern Arabian Sea along with Bay of Bengal) realms divided into different time periods, which would help us to understand the spatiotemporal variability and complexity of the south Asian monsoon. The focus of this paper is the high-resolution records with accurate, absolute chronology since Last Glacial Maximum $(\sim 21,000$ years before present) - a period which covers extensive glaciation, deglacial period witnessing rapid climatic fluctuations, and finally the Holocene (past $\sim 11,700$ years, [4]), which is a period of relatively unvarying warmth.
2.1. Monsoon and Associated Oceanographic Effects from Marine Proxies. During the summer and winter monsoons the surface oceanic circulation in the Northern Indian Ocean (Arabian Sea and Bay of Bengal) experiences changes in direction in consonance with the changing wind patterns $[50,51]$. Intense upwelling occurs along the Somalian and Oman coasts with a transport of $1.5-2 \mathrm{~Sv}$ in the upper $50 \mathrm{~m}$ [52]. The typical temperature of the upwelled water is 19$24^{\circ} \mathrm{C}$ [53]. The reason attributed for such intense coastal upwelling is the Ekman divergence due to the flow of strong winds parallel to the coast. The central Arabian Sea exhibits a bowl-shaped mixed layer deepening under the effect of Findlater Jet wind-stress forcing and Ekman pumping $[54,55]$. The cold and dry Northeast monsoon winds accompanied by the Ekman pumping cause subduction of the high salinity surface waters in the northern Arabian Sea $[56,57]$.

The upwelling zones along the Somalian and Oman coasts cause intense biological and geochemical changes in this region with SST falling by $\sim 4^{\circ} \mathrm{C}$ as nutrient-rich deeper water surfaces that enhance the sea surface biological productivity considerably $[9,50,58]$. Weak upwelling also occurs along coastal southwest India [50,59]. During the Northeast monsoon, minor upwelling is observed in the northeastern Arabian Sea [50]. The cold and dry NE monsoon winds cause the deepening of the mixed layer to a depth of 100-125 $\mathrm{m}$ due to convective mixing in the northern Arabian Sea, which leads to nutrient injection and hence high productivity during winter monsoon in this region [60, 61]. The typical productivity values for the western Arabian Sea are $2.0,1.0$, and $0.5 \mathrm{~g} \mathrm{C} / \mathrm{m}^{2} /$ day for the $\mathrm{SW}$ monsoon, $\mathrm{NE}$ monsoon, and the intermonsoon periods, respectively $[62,63]$. Similarly for the eastern Arabian Sea the typical productivity values are $0.6,0.3$, and $0.2 \mathrm{gC} / \mathrm{m}^{2} /$ day for the SW monsoon, NE monsoon, and the intermonsoon periods, respectively [64]. As the moisture laden SW monsoon winds approach the Western Ghats they are forced to ascend resulting in copious precipitation and runoff into the coastal Arabian Sea, reducing the sea surface salinity considerably [21]. Denitrification takes place due to the very low concentration of oxygen in the entire Arabian Sea from $250 \mathrm{~m}$ to $1250 \mathrm{~m}$ water depths $[65,66]$. This oxygen minimum zone (OMZ) is due to the high-oxygen consumption below the thermocline for the oxidation of organic matter supplied by the high overhead surface productivity. Furthermore the sluggish flow of the oxygen poor intermediate water $[66,67]$ along with a strong tropical thermocline (due to relatively high SST that prevents mixing of the oxygen-rich surface waters with the deeper waters) maintains the OMZ $[68,69]$. Thus OMZ and denitrification are the interplay of monsoon winds and the ensuing productivity along with other climatically controlled factors such as ocean ventilation rate $[40,70-73]$.

Such pronounced changes in the seawater characteristics make the Arabian Sea ideal for deciphering the past changes in monsoon intensity. The surface productivity that manifests itself in many forms such as organic, calcareous, and siliceous productivity, also affects the carbon isotopic composition of the seawater, which is preserved in the calcitic 


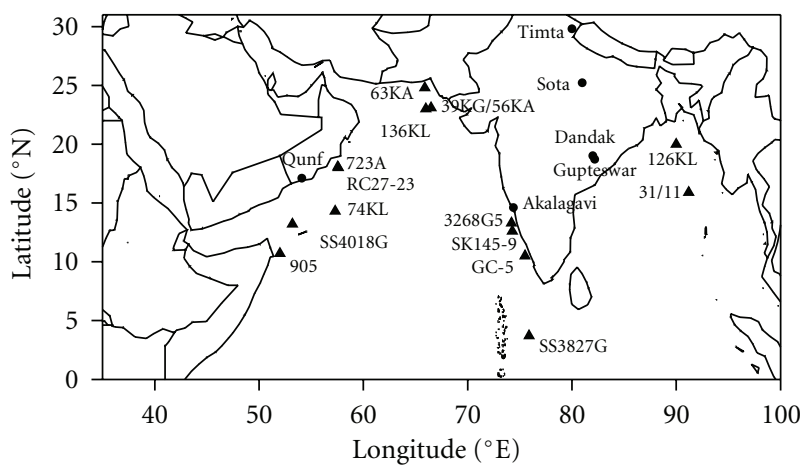

Figure 1: Sample locations discussed in the text. Triangles represent the marine-based records: 905 [78]; SS4018G [10]; 74KL [16]; RC27-23 [73]; 723A [19, 20]; 63KA [44]; 39KG/56KA [41]; 136KL [40]; 3268G5 [21]; SK145-9 [23]; GC-5 [22]; SS3827G [24]; 126KL [36]; 31/11 [37]. Circles represent terrestrial speleothem records: Qunf [32]; Akalagavi [31]; Gupteswar, Dandak [30]; Sota [86]; Timta [87].

shells of various foraminifera. Similarly the SST and sea surface salinity alter the oxygen isotopic composition of these shells and they get recorded in the sea sediments. The nitrogen isotopic composition of sedimentary organic matter can indicate the denitrification intensity relatable to productivity variations. Thus the downcore variations of such proxies could help document the past variations in monsoon intensity and the related climatic changes.

\section{Discussion}

Paleomonsoon studies in the Indian region were initiated around 30 years ago by Prell et al. [74] and Bryson and Swain [75]. Since then, a large number of workers ([2, 16-27, 29-32, 41-44, 76-78] and references therein) have carried out high-resolution monsoon studies in archives from various locations in and around the subcontinent that are influenced by the monsoon winds/precipitation. The data thus generated has helped document the fluctuations in the past monsoon strength both in space and time. Different proxies such as planktic/benthic foraminiferal abundances, their stable oxygen and carbon isotope ratios $[18,19,21$, 23, 24, 76, 77], varved sediments [41, 42], speleothems [2, 29-32], tree-rings [79], $\delta^{13} \mathrm{C}$ and $\delta^{15} \mathrm{~N}$ of lacustrine and marine organic matter $[10,73,80-83]$, and pollen records $[84,85]$ have been used to obtain paleomonsoon records with different resolutions. A few of the important proxies and their significance are shown in Table 2.

Recent marine studies have the advantage of accurate AMS (Accelerator Mass Spectrometry) ${ }^{14} \mathrm{C}$ dating, and in some case, have provided time resolutions as low as $\sim 50$ years (e.g., [23]) that can go up to subdecadal scale in extreme cases such as varved sediments [41]. The past strength of SWM was elucidated by using the above proxies from different monsoon-sensitive geographical regime (Figure 1) such as (i) the western Arabian Sea-experiences high productivity due to SWM wind induced upwelling [16-19, 76, 77]thus record strength of monsoon winds; (ii) the northern

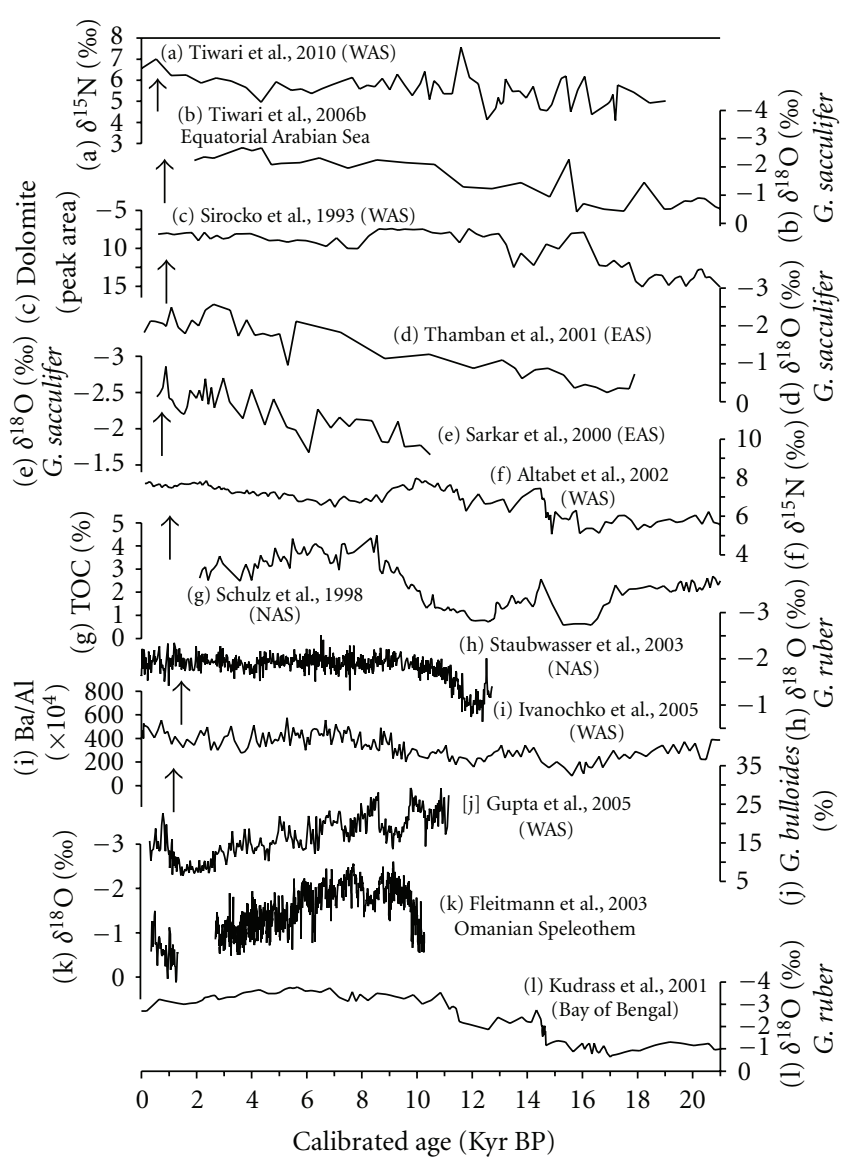

FIGURE 2: Variability in monsoon strength as deciphered from multiple proxies from various studies from different regions (EAS: Eastern Arabian Sea, WAS: Western Arabian Sea, NAS: Northern Arabian Sea); the arrows in each case depict increasing monsoon direction.

Arabian Sea-affected by amount of Indus river discharge $[43,44]$ and associated varve thickness $[41,42]$ relatable to SWM precipitation intensity; (iii) India and Omanthe growth rates and stable oxygen and carbon records of speleothems were used to quantitatively reconstruct SWM precipitation intensity $[2,29,30,32,86]$; (iv) the southeastern Arabian Sea sediment cores which are influenced by the surface runoff due to SWM precipitation from the western Ghats of India [21, 23, 25] - thus records strength of SWM precipitation; ( $\mathrm{v}$ ) water discharge from the GangaBrahmaputra (G-B) river system into the Bay of Bengal (BOB) [35-37]. The major inferences drawn from these regions have been presented in Table 1. For Indian populace, the more important aspect of monsoon is precipitation variability that may result in severe droughts or devastating floods. Therefore it is more important to decipher this aspect for which eastern Arabian Sea is better suited than other regions of Indian Ocean. From the comparative analysis, as represented in Figure 2, among different regions, it is clear that at short-time scales, monsoon exhibits a high-spatial variability-different regions experience different trends in monsoon intensity. But when we look at multi-millennial 


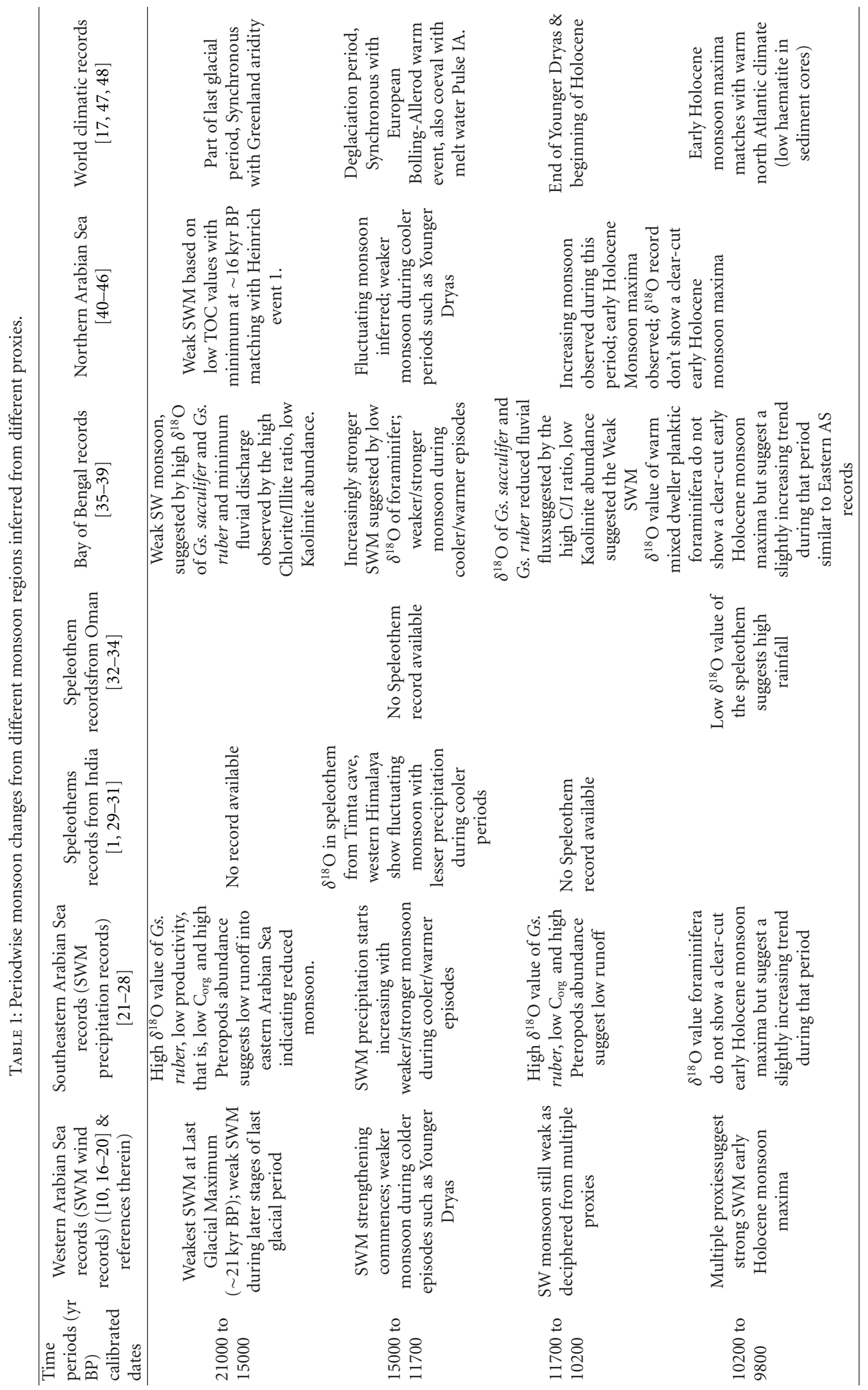




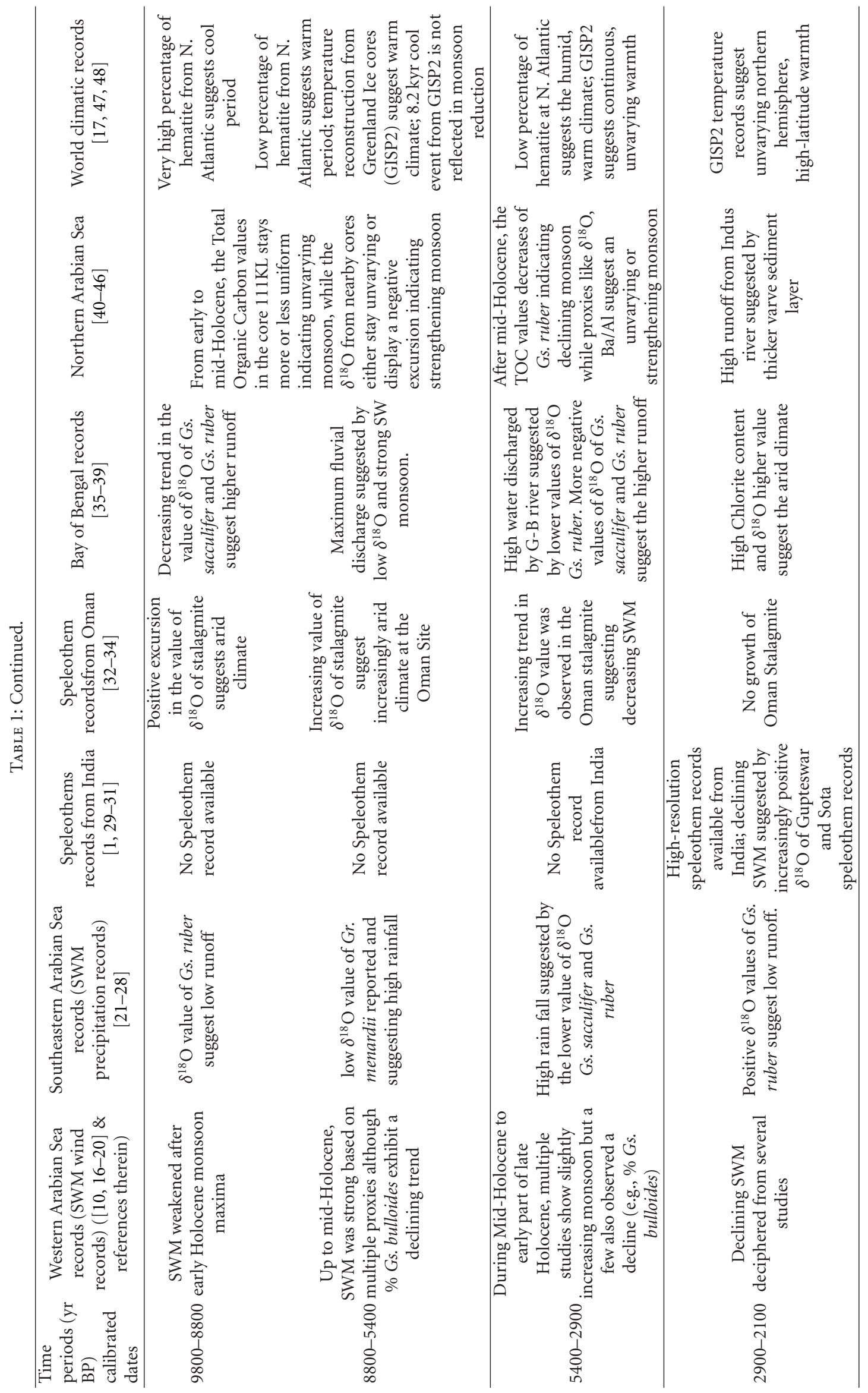




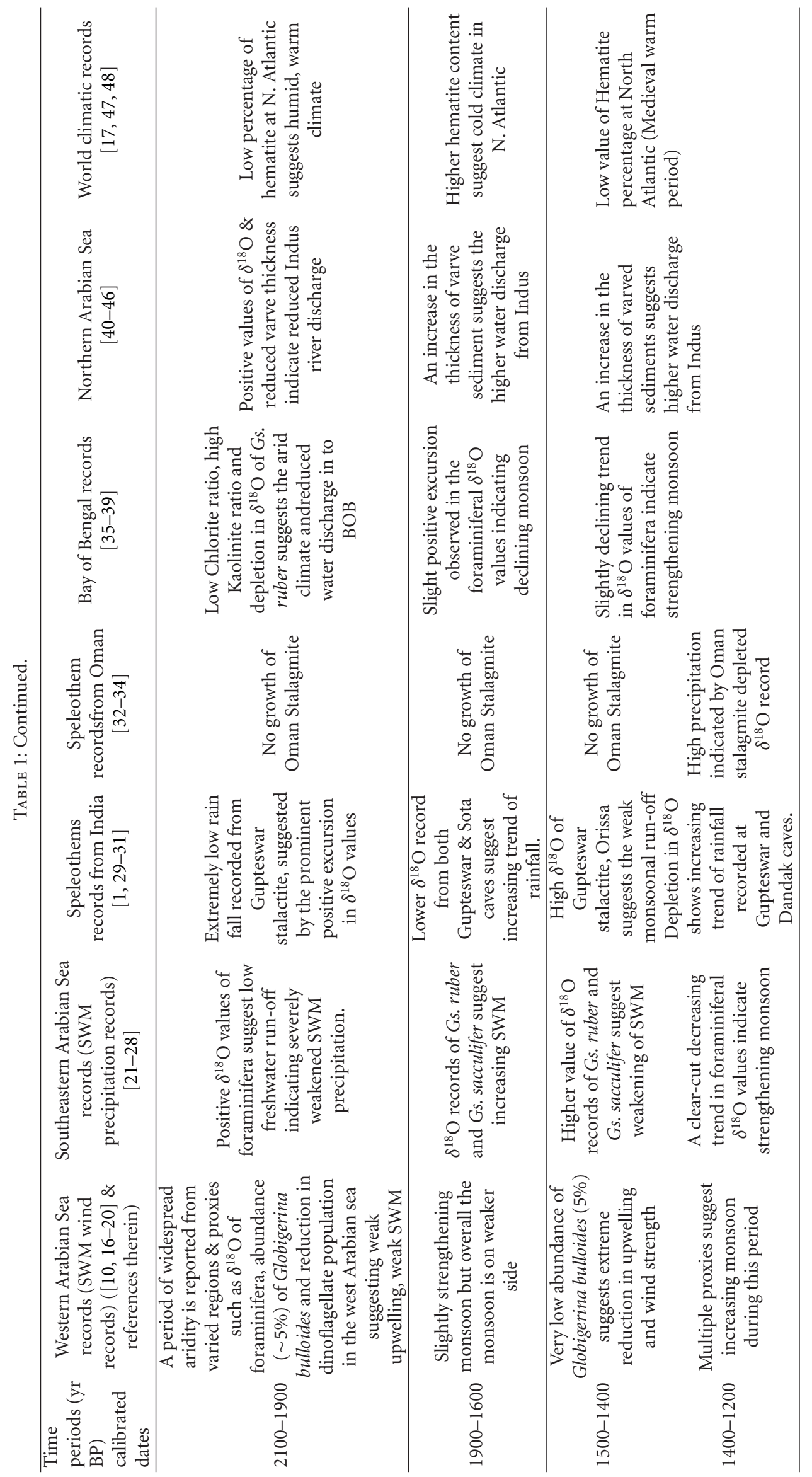




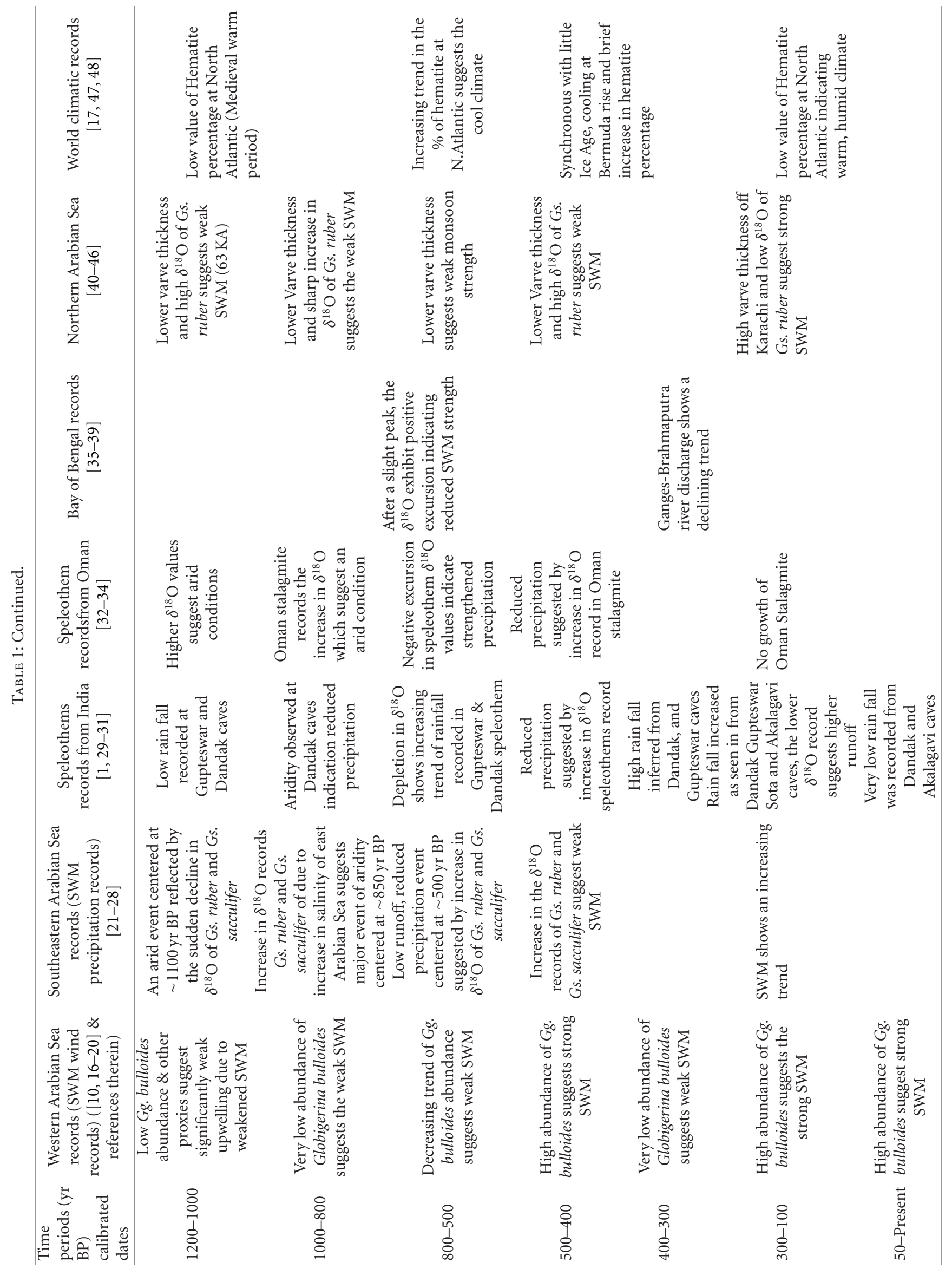


TABLE 2: A few of the important proxies/archives used for monsoon reconstruction and their significance.

S. No.
proxies/archives discussed in the
presentign

Oxygen isotopes of Speleothems and Foraminifera

Oxygen isotopes of foraminifera reflect the isotopic composition of the seawater that depends on salinity and temperature. Eastern Arabian Sea receives abundant fresh water as either direct precipitation or runoff from the adjacent Western Ghats during the Southwest monsoon. This reduces the sea surface salinity (SSS) that is reflected in negative excursion in the oxygen isotopic composition of planktic foraminifera.

The spatial distribution of Globigerina bulloides in the world ocean shows that it is dominant in temperate subpolar water mass and thus the only likely cause for high abundance in low latitude areas (tropical oceans) has been upwelling induced productivity. The initiation of upwelling in the western Arabian Sea and the subsequent increase in Globigerina bulloides flux indicates that foraminiferal population respond within a few weeks to changes in near surface hydrography, which has been demonstrated in studies from Western Arabian Sea Sediment Trap data. The enhanced upwelling in the Arabian Sea, especially western region, is strongly correlated to Southwest monsoon.

Kinetic isotope effects during photosynthesis cause preferential uptake of ${ }^{12} \mathrm{C}$ in the organic matter, which enriches the ambient dissolved bicarbonate in heavier

Carbon isotopes of foraminifera isotopes $\left({ }^{13} \mathrm{C}\right)$. The foraminifera secreting calcareous shells in equilibrium with the ambient water will record these isotopic signatures. Thus a higher $\delta^{13} \mathrm{C}$ value probably corresponds to an enhanced rate of photosynthesis in the euphotic layer that indicates an increase in productivity relatable to stronger monsoon.

Due to lack of oxygen in Oxygen Minima Zone, the anaerobic bacteria utilize $\mathrm{NO}_{3}{ }^{-}$ for the decomposition of organic matter. During this process they preferentially consume $\mathrm{NO}_{3}{ }^{-}$with lighter isotope $\left({ }^{14} \mathrm{~N}\right)$, thus enriching the residual nitrate in the heavier isotope, which gets upwelled to the sea surface and is taken by the organisms as a nutrient. This enriched nitrogen isotopic signature is preserved even when the organic matter settles down and gets preserved in sea sediments. Thus a high $\delta^{15} \mathrm{~N}$ can be related to increased denitrification, which in turn is controlled by the productivity increase relatable to monsoon strength.

Total Organic Carbon (TOC) preserved in the sea sediments is derived from the particulate organic carbon (POC, the carbon content of particulate organic matter) and is a manifestation of the overhead primary productivity if there are no alterations after the deposition. The overhead rain of calcitic shells is a major constituent of the sea sediments. It has been observed that during the monsoon season in the Arabian Sea, $50-60 \%$ of the total flux to the bottom is composed of calcitic material. Thus calcium carbonate percentage in the sea sediments can indicate the overhead productivity provided the core has been raised from depths above the lysocline $(\sim 3800 \mathrm{~m}$ in the Arabian Sea) and there is no contamination from the terrigenous inputs

time scales then we find that monsoon records from varied realms exhibit similar trends.

Fleitmann et al. [32] deciphered declining SWM precipitation during the Holocene based on speleothems from Oman. But this region is near the edge of the monsoon precipitation and receives very little rain as compared to the Indian subcontinent. Moreover, such arid/semiarid regions with dynamic karstic terrains have been reported to have long residence time of water up to decades [88]. Also, the strong evaporation in such regions could greatly alter the $\delta^{18} \mathrm{O}$ of precipitation during infiltration and in the upper portion of the vadose zone [89], making such reconstructions somewhat ambiguous. In the western Arabian Sea during the Holocene, a few of the SWM wind intensity, based proxies (e.g., content of G. bulloides-a calcareous micro-organism flourishing in the cooler, upwelled waters during SWM season) showed that monsoon winds have been declining, following the reduction in insolation. On the other hand, studies from the eastern Arabian Sea, which record SWM precipitation, have indicated otherwise. The eastern Arabian Sea receives abundant fresh water as either direct precipitation or runoff from the adjacent Western Ghats (Sahyadri Hills) that induces intense orographic precipitation during the SW monsoon. This reduces the sea surface salinity (SSS) that is reflected in the oxygen isotopic composition $\left(\delta^{18} \mathrm{O}\right)$ of planktic foraminifera. Such reconstructions have indicated increasing strength of SWM precipitation during the Holocene [21, 22, 27]. Similarly, Agnihotri et al. [28] have found increasing productivity during the Holocene based on denitrification intensity 
$\left(\delta^{15} \mathrm{~N}\right)$, which is relatable to SWM strength. To resolve this apparent contradiction between the studies from the western and the eastern margins of the Arabian Sea, Tiwari et al. [10] studied productivity proxies from the western Arabian Sea. They found out that the reason for declining trend observed in the planktic carbonate production (relative abundance (\%) of G. bulloides-[19] and declining $\% \mathrm{CaCO}_{3}-[10]$ ) is the preference to silicate productivity over calcareous productivity during periods of enhanced monsoon winds. During initial stages of SWM (weaker monsoon winds), upwelling takes place from shallower regions bringing nitrate and phosphate to the surface that supports calcareous microorganisms. But as the monsoon progresses and the winds became stronger, upwelling takes place from the deeper waters, injecting silicate to the photic zone, which enhances siliceous productivity $[90,91]$. This has been observed in sediment records of past climate as well [45, 92]. Other productivity indicators (organic carbon, $\delta^{15} \mathrm{~N}$, $\delta^{13} \mathrm{C}$ of three species of foraminifera) analyzed by Tiwari et al. [10] unambiguously indicate strengthening monsoon during Holocene, unlike insolation that declines during the same period. This multiproxy result indicates that, on sub-Milankovitch, multi-millennial timescales, monsoon is predominantly governed by internal feedback mechanisms and lagged summer insolation maxima by several thousand years, as noted earlier by Clemens et al. [49].

\section{Conclusions}

In essence, the above discussion shows that there exists a large spatial variability in monsoon records, which becomes more pronounced on shorter timescales. But on longer time scales, a more coherent picture emerges. On glacialinterglacial time scales, SWM was stronger (weaker) during the warmer (colder) periods, with a minimum during the Last Glacial Maximum. During deglaciation, monsoon fluctuated widely with weaker monsoons during colder episodes such as Younger Dryas and stronger monsoons during warm episodes such as Bølling-Allerød. During the early Holocene, a widely reported SWM maximum is followed by a decline. Thereafter, during the Holocene, the SWM either stayed uniform or showed decline only after the mid-Holocene, which needs to be verified further with accurately dated records from both the western and eastern Arabian Sea margins. During the Holocene, monsoon did not decline following the reducing insolation, which highlights the importance of internal feedback mechanisms. On short time scales (millennial to subcentennial), a period of widespread aridity is reported at $\sim 2000 \mathrm{yr} \mathrm{BP}$ followed by arid periods at $\sim 1500 \mathrm{yr} \mathrm{BP}, \sim 1100 \mathrm{yr} \mathrm{BP}, \sim 850 \mathrm{yr} \mathrm{BP}$, and $\sim 500 \mathrm{yr} \mathrm{BP}$ [23]. On such short time scales (centennial to subcentennial), monsoon has been reported to follow insolation [93]. This highlights complex dynamics of SWM at different timescales. This intercomparison of monsoon records from different regions show that despite the considerable spatial variability in monsoon strength, it increases during warmer periods in general. This indicates that monsoon may strengthen in the future scenario of global warming that corroborates the model results represented in IPCC AR4. An understanding of this requires systematic studies covering various regions under the SWM realm using multiple proxies at different spatiotemporal scales.

\section{Acknowledgments}

The authors thank ISRO-GBP for funding. M. Tiwari thanks the Director-NCAOR for encouragement. A. K. Singh thanks Delhi University for support. This is NCAOR Contribution no. $06 / 2011$.

\section{References}

[1] R. Ramesh and M. G. Yadava, "Climate and water resources of india," Current Science, vol. 89, no. 5, pp. 818-824, 2005.

[2] R. Ramesh, "High resolution holocene monsoon records from different proxies: an assessment of their consistency," Current Science, vol. 81, no. 11, pp. 1432-1436, 2001.

[3] M. Tiwari, S. Managave, M. G. Yadava, and R. Ramesh, "Spatial and temporal coherence of paleomonsoon records from marine and land proxies in the indian region during the past $30 \mathrm{ka}$," in Platinum Jubilee Special Publication of the Indian Academy of Sciences, N. Mukunda, Ed., pp. 517-535, Bangaluru, India, 2009.

[4] R. Ramesh, M. Tiwari, S. Chakraborty, S. Managave, M. G. Yadava, and D. K. Sinha, "Retrieval of south asian monsoon variation during the holocene form natural climate archives," Current Science, vol. 99, no. 12, pp. 1770-1786, 2010.

[5] R. Korisettar and R. Ramesh, "The indian monsoon: roots, relations and relevance," in Archaeology and Interactive Disciplines, S. Settar and R. Korisettar, Eds., vol. III of Indian Archaeology in Retrospect, pp. 23-59, Indian Council of Historical Research, Manohar Publications, New Delhi, India, 2002.

[6] A. K. Singh, M. G. Yadava, and R. Ramesh, "High resolution monsoon records from land and the ocean: what have we learnt during the last decade?" Jal Vigyan Sameeksha (Hydrology Review), vol. 22, pp. 177-190, 2007.

[7] P. J. Webster, "The elementary monsoon," in Monsoons, J. S. Fein and L. Stephens, Eds., pp. 3-32, John Wiley \& sons, New York, NY, USA, 1987.

[8] P. J. Webster, V. O. Magaña, T. N. Palmer et al., "Monsoons: processes, predictability, and the prospects for prediction," Journal of Geophysical Research C, vol. 103, no. 7, pp. 1445114510, 1998.

[9] R. R. Nair, V. Ittekkot, B. Haake et al., "Increased particle flux to the deep ocean related to monsoons," Nature, vol. 338, no. 6218, pp. 749-751, 1989.

[10] M. Tiwar, R. Ramesh, R. Bhushan et al., "Did the Indo-Asian summer monsoon decrease during the holocene following insolation?" Journal of Quaternary Science, vol. 25, no. 7, pp. 1179-1188, 2010.

[11] A. Sarkar, R. Ramesh, S. K. Bhattacharya, and G. Rajagopalan, "Oxygen isotope evidence for a stronger winter monsoon current during the last glaciation," Nature, vol. 343, no. 6258, pp. 549-551, 1990.

[12] V. S. Kale, L. I. Ely, Y. Enzel, and V. R. Baker, "Geomorphic and hydrologic aspects of monsoon floods on the narmada and tapi rivers in central india," Geomorphology, vol. 10, no. 1-4, pp. 157-168, 1994.

[13] M. Tiwari, R. Ramesh, B. L. K. Somayajulu, A. J. T. Jull, and G. S. Burr, "Early deglacial ( $19-17 \mathrm{ka})$ strengthening of the northeast monsoon," Geophysical Research Letters, vol. 32, no. 19, Article ID L19712, pp. 1-4, 2005. 
[14] S. R. Managave, M. S. Sheshshayee, R. Ramesh, H. P. Borgoankar, S. K. Shah, and A. Bhattacharyya, "Response of cellulose oxygen isotope values of teak trees in differing monsoon environments to monsoon rainfall," Dendrochronologia, vol. 29, no. 2, pp. 89-97, 2011.

[15] G. B. Pant and K. R. Kumar, Climates of South Asia. Belhaven Studies in Climatology, Belhaven Studies in Climatology, John Wiley \& Sons, Chichester, NY, USA, 1997.

[16] F. Sirocko, M. Sarnthein, H. Erlenkeuser, H. Lange, M. Arnold, and J. C. Duplessy, "Century-scale events in monsoonal climate over the past 24,000 years," Nature, vol. 364, no. 6435, pp. 322-324, 1993.

[17] F. Sirocco, D. G. Sconberg, A. McIntyre, and B. Molfino, "Teleconnections between the subtropical monsoon \& high latitude climates during the last glaciations," Science, vol. 272, pp. 526-529, 1996.

[18] D. M. Anderson, J. T. Overpeck, and A. K. Gupta, "Increase in the asian SW monsoon during the past four centuries," Science, vol. 297, no. 5581, pp. 596-599, 2002.

[19] A. K. Gupta, D. M. Anderson, and J. T. Overpeck, "Abrupt changes in the Asian Southwest monsoon during the holocene and their links to the North Alantic ocean," Nature, vol. 421, no. 6921, pp. 354-357, 2003.

[20] A. K. Gupta, M. Das, and D. M. Anderson, "Solar influence on the indian summer monsson during the holocene," Geophysical Research Letters, vol. 32, no. 17, Article ID L17703, pp. 1-4, 2005.

[21] A. Sarkar, R. Ramesh, B. L. K. Somayajulu, R. Agnihotri, A. J. T. Jull, and G. S. Burr, "High resolution holocene monsoon record from the eastern arabian sea," Earth and Planetary Science Letters, vol. 177, no. 3-4, pp. 209-218, 2000.

[22] M. Thamban, V. Purnachandra Rao, R. R. Schneider, and P. M. Grootes, "Glacial to holocene fluctuations in hydrography and productivity along the southwestern continental margin of india," Palaeogeography, Palaeoclimatology, Palaeoecology, vol. 165, no. 1-2, pp. 113-127, 2001.

[23] M. Tiwari, R. Ramesh, M. G. Yadava, B. L. K. Somayajulu, A. J. T. Jull, and G. S. Burr, "Is there a persistent control of monsoon winds by precipitation during the late holocene?" Geochemistry, Geophysics, Geosystems, vol. 7, no. 3, Article ID Q03001, pp. 1-7, 2006.

[24] M. Tiwari, R. Ramesh, B. L. K. Somayajulu, A. J. T. Jull, and G. S. Burr, "Paleomonsoon precipitation deduced from a sediment core from the equatorial indian ocean," Geo-Marine Letters, vol. 26, no. 1, pp. 23-30, 2006.

[25] A. D. Singh, D. Kroon, and R. S. Ganeshram, "Millennial scale variations in productivity and OMZ intensity in the eastern arabian sea," Journal of the Geological Society of India, vol. 68, no. 3, pp. 369-377, 2006.

[26] O. S. Chauhan, E. Vogelsang, N. Basavaiah, and U. S. A. Kader, "Reconstruction of the variability of the southwest monsoon during the past $3 \mathrm{ka}$, from the continental margin of the southeastern arabian sea," Journal of Quaternary Science, vol. 25, no. 5, pp. 798-807, 2009.

[27] P. Govil and P. D. Naidu, "Evaporation-precipitation changes in the eastern arabian sea for the last $68 \mathrm{ka}$ : implications on monsoon variability," Paleoceanography, vol. 25, article PA1210, 11 pages, , 2010.

[28] R. Agnihotri, S. K. Bhattacharya, M. M. Sarin, and B. L. K. Somayajulu, "Changes in surface productivity and subsurface denitrification during the holocene: a multiproxy study from the eastern arabian sea," Holocene, vol. 13, no. 5, pp. 701-713, 2003.
[29] M. G. Yadava and R. Ramesh, "Past rain fall and trace element variations in a tropical speleothem from india," Mausam, vol. 52, pp. 307-316, 2001.

[30] M. G. Yadava and R. Ramesh, "Monsoon reconstruction from radiocarbon dated tropical indian speleothems," Holocene, vol. 15, no. 1, pp. 48-59, 2005.

[31] M. G. Yadava, R. Ramesh, and G. B. Pant, "Past monsoon rainfall variations in peninsular india recorded in a 331 year old speleothem," Holocene, vol. 14, no. 4, pp. 517-524, 2004.

[32] D. Fleitmann, S. J. Burns, M. Mudelsee et al., "Holocene forcing of the indian monsoon recorded in a stalagmite from southern oman," Science, vol. 300, no. 5626, pp. 1737-1739, 2003.

[33] U. Neff, S. J. Burns, A. Mangini, M. Mudelsee, D. Fleitmann, and A. Matter, "Strong coherence between solar variability and the monsoon in oman between 9 and 6 kyr ago," Nature, vol. 411, no. 6835, pp. 290-293, 2001.

[34] S. J. Burns, D. Fleitmann, M. Mudelsee, U. Neff, A. Matter, and A. Mangini, "A 780-year annually resolved record of indian ocean monsoon precipitation from a speleothem from south man," Journal of Geophysical Research D, vol. 107, no. 20, pp. $1-9,2002$.

[35] O. S. Chauhan, D. V. Borole, A. R. Gujar, M. Antonio, P. G. Mislanker, and C. M. Rao, "Evidences of climatic variations during late pleistocene-holocene in the eastern bay of bengal," Current Science, vol. 65, no. 7, pp. 558-562, 1993.

[36] H. R. Kudrass, A. Hofmann, H. Doose, K. Emeis, and H. Erlenkeuser, "Modulation and amplification of climatic changes in the northern hemisphere by the indian summer monsoon during the past $80 \mathrm{kyr}$," Geology, vol. 29, no. 1, pp. 63-66, 2001.

[37] O. S. Chauhan, "Past 20,000-year history of himalayan aridity: evidence from oxygen isotope records in the bay of bengal," Current Science, vol. 84, no. 1, pp. 90-93, 2003.

[38] M. E. Weber, M. H. Wiedicke, H. R. Kudrass, C. Hübscher, and $\mathrm{H}$. Erlenkeuser, "Active growth of the bengal fan during sealevel rise and highstand," Geology, vol. 25, no. 4, pp. 315-318, 1997.

[39] S. M. Ahmad, G. A. Babu, V. M. Padmakumari, and W. Raza, "Surface and deep water changes in the northeast indian ocean during the last $60 \mathrm{ka}$ inferred from carbon and oxygen isotopes of planktonic and benthic foraminifera," Palaeogeography, Palaeoclimatology, Palaeoecology, vol. 262, no. 3-4, pp. 182188, 2008.

[40] H. Schulz, U. Von Rad, and H. Erlenkeuser, "Correlation between arabian sea and greenland climate oscillations of the past 110,000 years," Nature, vol. 393, no. 6680, pp. 54-57, 1998.

[41] U. Von Rad, M. Schaaf, K. H. Michels, H. Schulz, W. H. Berger, and F. Sirocko, "A 5000-yr record of climate change in varved sediments from the oxygen minimum zone off Pakistan, Northeastern Arabian sea," Quaternary Research, vol. 51, no. 1, pp. 39-53, 1999.

[42] U. Von Rad, A. Lückge, W. H. Berger, and H. D. Rolinski, "Annual to millennial monsoonal cyclicity recorded in holocene varved sediments from the NE arabian sea," Journal of the Geological Society of India, vol. 68, no. 3, pp. 353-368, 2006.

[43] M. Staubwasser, F. Sirocko, P. M. Grootes, and M. Segl, "Climate change at the $4.2 \mathrm{ka}$ BP termination of the indus valley civilization and holocene south asian monsoon variability," Geophysical Research Letters, vol. 30, no. 8, pp. 7-1, 2003.

[44] M. Staubwasser, F. Sirocko, P. M. Grootes, and H. Erlenkeuser, "South Asian monsoon climate change and radiocarbon in the 
arabian sea during early and middle holocene," Paleoceanography, vol. 17, no. 4, pp. 15-1, 2002.

[45] G. J. Reichart, M. Den Dulk, H. J. Visser, C. H. Van Der Weijden, and W. J. Zachariasse, "A 225 kyr record of dust supply, paleoproductivity and the oxygen minimum zone from the murray ridge (Northern Arabian Sea)," Palaeogeography, Palaeoclimatology, Palaeoecology, vol. 134, no. 1-4, pp. 149169, 1997.

[46] M. Staubwasser, "An overview of holocene south asian monsoon records - monsoon domains and regional contrasts," Journal of the Geological Society of India, vol. 68, no. 3, pp. 433446, 2006.

[47] W. Dansgaard, S. J. Johnsen, H. B. Clausen et al., "Evidence for general instability of past climate from a $250 \mathrm{kyr}$ ice-core record," Nature, vol. 364, no. 6434, pp. 218-220, 1993.

[48] G. Bond, B. Kromer, J. Beer et al., "Persistent solar influence on north atlantic climate during the holocene," Science, vol. 294, no. 5549, pp. 2130-2136, 2001.

[49] S. C. Clemens, W. Prell, G. Murray, G. Shimmield, and G. Weedon, "Forcing mechanisms of the indian ocean monsoon," Nature, vol. 353, no. 6346, pp. 720-725, 1991.

[50] K. Wrytki, "Physical oceanography of the indian ocean," in The Biology of the Indian Ocean, B. Zeitzschel, Ed., pp. 18-36, Springer-Verlag, New York, NY, USA, 1973.

[51] F. Schott, J. C. Swallow, and M. Fieux, "The Somali current at the equator: annual cycle of currents and transports in the upper $1000 \mathrm{~m}$ and connection to neighbouring latitudes," Deep Sea Research Part A, vol. 37, no. 12, pp. 1825-1848, 1990.

[52] R. L. Smith and J. S. Bottero, "On upwelling in the arabian sea," in A Voyage of Discovery, M. Angel, Ed., pp. 291-304, Pergamon Press, New York, NY, USA, 1977.

[53] F. A. Schott and J. P. McCreary, "The monsoon circulation of the indian ocean," Progress in Oceanography, vol. 51, no. 1, pp. 1-123, 2001.

[54] J. P. McCreary and P. K. Kundu, "A numerical investigation of sea surface temperature variability in the arabian sea," Journal of Geophysical Research, vol. 94, no. 11, pp. 16-114, 1989.

[55] R. R. Rao and R. Sivakumar, "Seasonal variability of nearsurface thermal structure and heat budget of the mixed layer of the tropical indian ocean from a new global ocean temperature climatology," Journal of Geophysical Research , vol. 105, no. 1, pp. 985-1015, 2000.

[56] J. M. Morrison, "Inter-monsoonal changes in the T-S properties of the near-surface waters of the northern arabian sea," Geophysical Research Letters, vol. 24, no. 21, pp. 2553-2556, 1997.

[57] F. Schott and J. Fischer, "Winter monsoon circulation of the northern arabian sea and somali current," Journal of Geophysical Research, vol. 105, no. 3, pp. 6359-6376, 2000.

[58] B. Haake, V. Ittekkot, T. Rixen, V. Ramaswamy, R. R. Nair, and W. B. Curry, "Seasonality and interannual variability of particle fluxes to the deep arabian sea," Deep-Sea Research Part I, vol. 40, no. 7, pp. 1323-1344, 1993.

[59] S. R. Shetye, "Seasonal variability of the temperature field off the south west coast of india," Proceedings of the Indian Academy of Sciences, vol. 93, no. 4, pp. 399-411, 1984.

[60] K. Banse and C. R. McClain, "Winter blooms of phytoplankton in the arabian sea as observed by the coastal zone colour scanner," Marine Ecology Progress Series, vol. 34, pp. 201-211, 1986.

[61] M. Madhupratap, S. P. Kumar, P. M. A. Bhattathiri et al., "Mechanism of the biological response to winter cooling in the northeastern arabian sea," Nature, vol. 384, no. 6609, pp. 549-552, 1996.
[62] L. A. Codispoti, "Primary productivity and carbon and nitrogen cycling in the arabian sea," in U.S. JGOFS: Arabian Sea Process study, S. L. Smith, K. Banse, J. K. Cochran et al., Eds., vol. 13, U.S. JGOFS Planning Report, 1991.

[63] R. T. Barber, J. Marra, R. C. Bidigare et al., "Primary productivity and its regulation in the arabian sea during 1995," Deep-Sea Research Part II, vol. 48, no. 6-7, pp. 1127-1172, 2001.

[64] P. M. A. Bhattathiri, A. Pant, S. Sawant, M. Gauns, S. G. P. Matondkar, and R. Mohanraju, "Phytoplankton production and chlorophyll distribution in the eastern and central arabian sea in 1994-1995," Current Science, vol. 71, no. 11, pp. 857-862, 1996.

[65] S. W. A. Naqvi, "Some aspects of the oxygen-deficient conditions and denitrification in the Arabian sea," Journal of Marine Research, vol. 45, no. 4, pp. 1049-1072, 1987.

[66] D. B. Olson, G. L. Hitchcock, R. A. Fine, and B. A. Warren, "Maintenance of the low-oxygen layer in the central arabian sea," Deep-Sea Research Part II, vol. 40, no. 3, pp. 673-685, 1993.

[67] Y. You and M. Tomczak, "Thermocline circulation and ventilation in the indian ocean derived from water mass analysis," Deep-Sea Research Part I, vol. 40, no. 1, pp. 13-56, 1993.

[68] D. Spencer, W. S. Broecker, H. Craig, and R. F. Weiss, "GEOSECS indian ocean expedition 6," Sections and Profiles, U.S. Government Printing Office, Washington, DC, USA, 1982.

[69] S. Z. Qasim, "Oceanography of the northern arabian sea," Deep Sea Research Part A, vol. 29, no. 9, pp. 1041-1068, 1982.

[70] G. J. Reichart, M. D. Dulk, H. J. Visser, C. H. Van Der Weijden, and W. J. Zachariasse, "A 225 kyr record of dust supply, paleoproductivity and the oxygen minimum zone from the murray ridge (Northern Arabian Sea)," Palaeogeography, Palaeoclimatology, Palaeoecology, vol. 134, no. 1-4, pp. 149169, 1997.

[71] G. J. Reichart, L. J. Lourens, and W. J. Zachariasse, “Temporal variability in the northern arabian sea oxygen minimum zone (OMZ) during the last 225,000 years," Paleoceanography, vol. 13, no. 6, pp. 607-621, 1998.

[72] G. J. Reichart, S. J. Schenau, G. J. De Lange, and W. J. Zachariasse, "Synchroneity of oxygen minimum zone intensity on the oman and pakistan margins at sub-milankovitch time scales," Marine Geology, vol. 185, no. 3-4, pp. 403-415, 2002.

[73] M. A. Altabet, M. J. Higginson, and D. W. Murray, "The effect of millennial-scale changes in arabian sea denitrification on atmospheric $\mathrm{CO}_{2}$," Nature, vol. 415, no. 6868, pp. 159-162, 2002.

[74] W. L. Prell, W. H. Hutson, D. F. Williams, A. W. H. Be, K. Geitzenauer, and B. Molfino, "Surface circulation of the indian ocean during the last glacial maximum, approximately 18 000 yr BP," Quaternary Research, vol. 14, no. 3, pp. 309-336, 1980.

[75] R. A. Bryson and A. M. Swain, "Holocene variations of monsoon rainfall in rajasthan," Quaternary Research, vol. 16, no. 2, pp. 135-145, 1981.

[76] P. D. Naidu and B. A. Malmgren, "A high-resolution record of late quaternary upwelling along the oman margin, arabian Sea based on planktonic foraminifera," Paleoceanography, vol. 11, no. 1, pp. 129-140, 1996.

[77] P. D. Naidu and B. A. Malmgren, "Seasonal sea surface temperature contrast between the holocene and last glacial 
period in the western arabian sea (Ocean Drilling Project Site 723A): modulated by monsoon upwelling," Paleoceanography, vol. 20, no. 1, pp. 1-9, 2005.

[78] T. S. Ivanochko, R. S. Ganeshram, G. J. A. Brummer et al., "Variations in tropical convection as an amplifier of global climate change at the millennial scale," Earth and Planetary Science Letters, vol. 235, no. 1-2, pp. 302-314, 2005.

[79] A. Bräuning and J. Griebinger, "Late Holocene variations in monsoon intensity in the Tibetan-Himalayan region-evidence from tree rings," Journal of the Geological Society of India, vol. 68, no. 3, pp. 485-493, 2006.

[80] Y. Enzel, L. L. Ely, S. Mishra et al., "High resolution holocene environmental changes in the thar desert, northwestern india," Science, vol. 284, no. 5411, pp. 125-128, 1999.

[81] R. Agnihotri, K. Dutta, R. Bhushan, and B. L. K. Somayajulu, "Evidence for solar forcing on the indian monsoon during the last millennium," Earth and Planetary Science Letters, vol. 198, no. 3-4, pp. 521-527, 2002.

[82] R. Ramesh and M. Tiwari, "Comment on "Monsoon related changes in sea surface productivity and water column denitrification in the eastern arabian sea during the last glacial cycle" by V.K. Banakar, T. Oba, A.R. Chodankar, T. Kuramoto, M. Yamamoto, M. Minagawa," Marine Geology, vol. 238, no. 14, pp. 119-120, 2007.

[83] R. Ramesh, M. S. Sheshshayee, and M. Tiwari, "Significance of $\delta^{15} \mathrm{~N}$ variations in a sediment core from the equatorial Indian Ocean during the past $\sim 35 \mathrm{ka}$," Current Science, vol. 93, no. 6, pp. 840-843, 2007.

[84] A. Bhattacharyya, P. S. Ranhotra, and S. K. Shah, "Temporal and spatial variations of late pleistocene-holocene climate of the western himalaya based on pollen records and their implications to monsoon dynamics," Journal of the Geological Society of India, vol. 68, no. 3, pp. 507-515, 2006.

[85] N. R. Phadtare and R. K. Pant, "A century-scale pollen record of vegetation and climate history during the past 3500 years in the pinder valley, kumaon higher himalaya, india," Journal of the Geological Society of India, vol. 68, no. 3, pp. 495-506, 2006.

[86] M. G. Yadava and R. Ramesh, "Stable oxygen and carbon isotope variations as monsoon proxies: a comparative study of speleothems from four different locations in india," Journal of the Geological Society of India, vol. 68, no. 3, pp. 461-475, 2006.

[87] A. Sinha, K. G. Cannariato, L. D. Stott et al., "Variability of southwest indian summer monsoon precipitation during the Bølling-Ållerød,” Geology, vol. 33, no. 10, pp. 813-816, 2005.

[88] A. Ayalon, M. Bar-Matthews, and E. Sass, "Rainfall-recharge relationships within a karstic terrain in the eastern mediterranean semi-arid region, israel: delta O-18 and delta D characteristics," Journal of Hydrology, vol. 207, no. 1-2, pp. 1831, 1998.

[89] F. McDermott, "Palaeo-climate reconstruction from stable isotope variations in speleothems: a review," Quaternary Science Reviews, vol. 23, pp. 901-918, 2004.

[90] T. Rixen, B. Haake-Gaye, V. Ittekkot, M. V. S. Guptha, R. R. Nair, and P. Schlüssel, "Coupling between SW monsoonrelated surface and deep ocean processes as discerned from continuous particle flux measurements and correlated satellite data," Journal of Geophysical Research C, vol. 101, no. 12, pp. 28569-28582, 1996.

[91] T. Rixen, B. Haake, and V. Ittekkot, "Sedimentation in the western arabian sea the role of coastal and open-ocean upwelling," Deep-Sea Research Part II, vol. 47, no. 9-11, pp. 2155-2178, 2000.
[92] D. W. Murray and W. L. Prell, "Pliocene to pleistocene variations in calcium carbonate, organic carbon, and opal on the owen ridge, Northern Arabian Sea," Proceedings of ODP Scientific Results, vol. 117, pp. 343-363, 1991.

[93] M. Tiwari and R. Ramesh, "Solar variability in the past and palaeoclimate data pertaining to the southwest monsoon," Current Science, vol. 93, no. 4, pp. 477-487, 2007. 

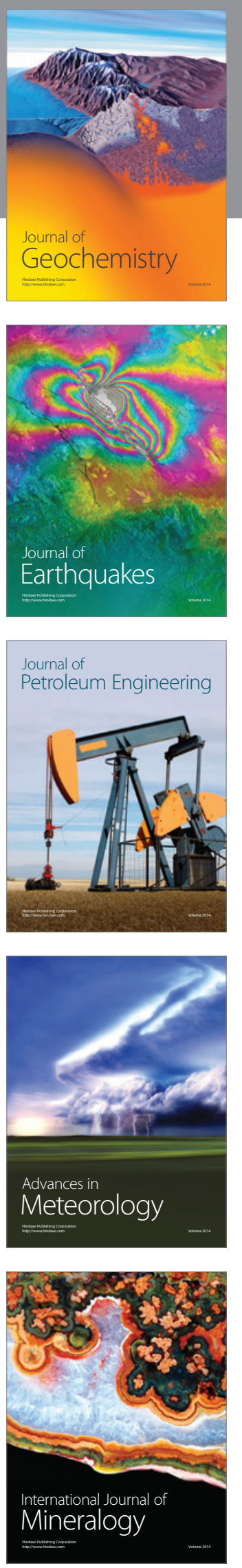
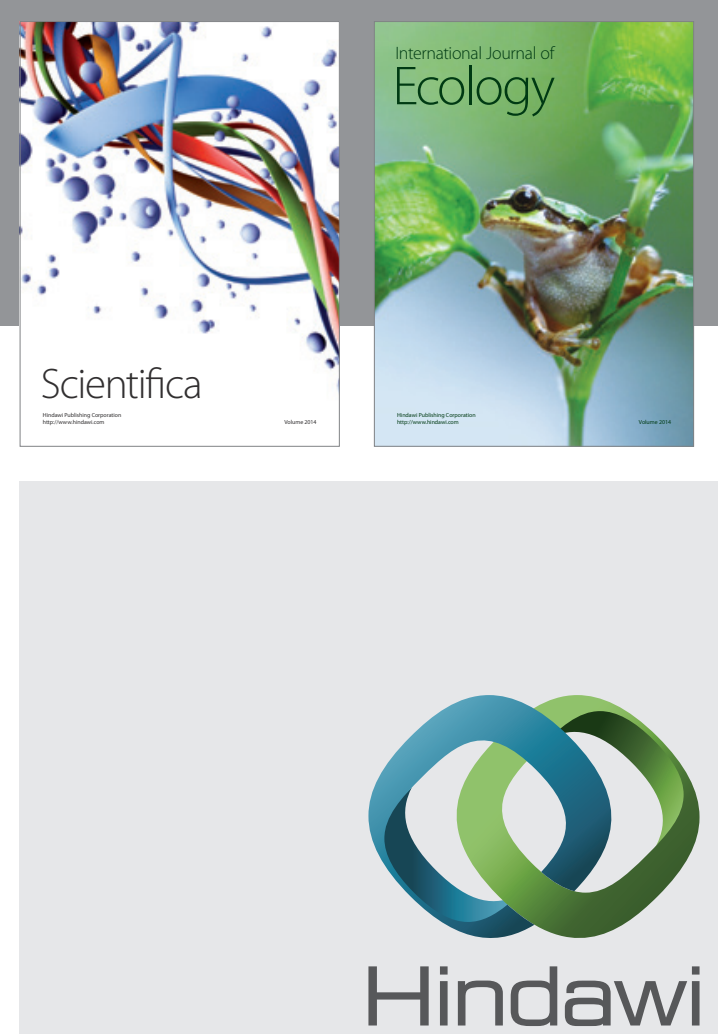

Submit your manuscripts at http://www.hindawi.com
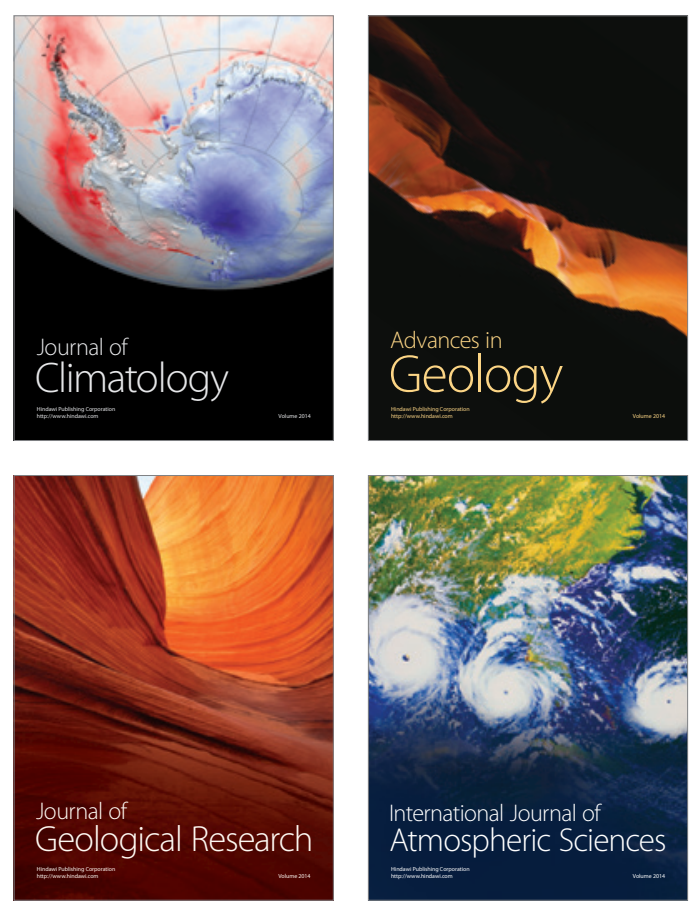
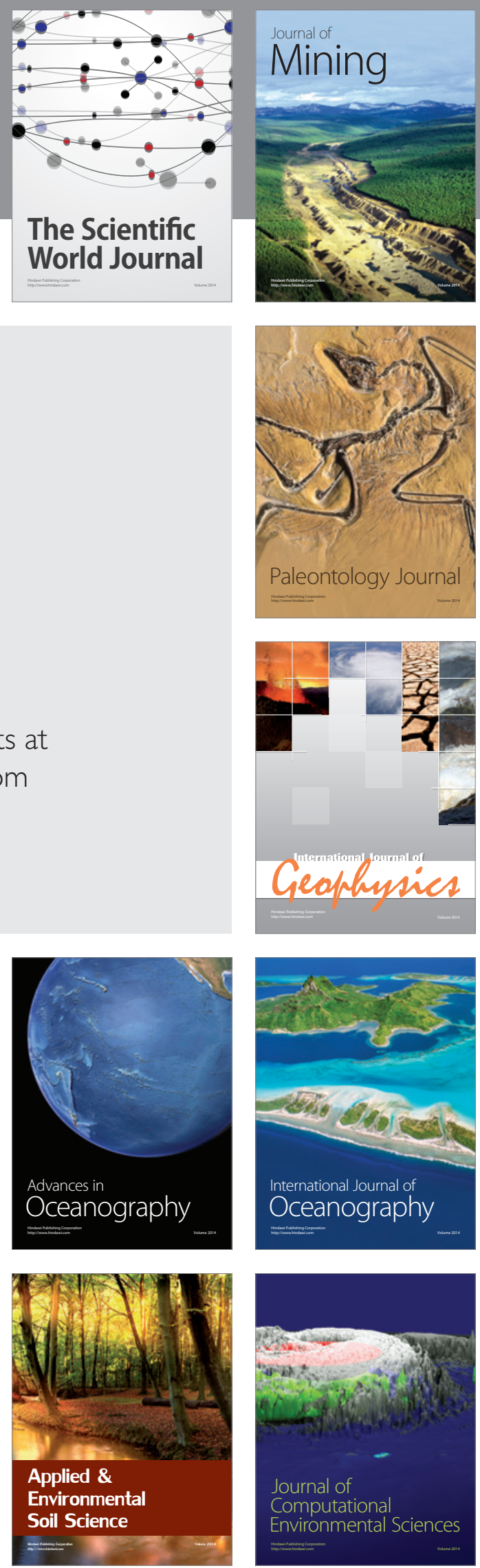